Indian J Anim Health (2021), 60(2)-Special Issue: 231-243

DOI: https://doi.org/10.36062/ijah.2021.spl.01921

\title{
Effect of pomegranate peel powder on cooked spent layers chicken meatballs $^{\#}$
}

\author{
D. Dhara ${ }^{1 *}$, S. Biswas ${ }^{1}$, O. Biswas ${ }^{2}$, G. Patra ${ }^{1}$ and P. Kandasawamy ${ }^{2}$ \\ ${ }^{1}$ Department of Livestock Products Technology, West Bengal University of Animal and Fishery \\ Sciences, Kolkata - 700 037, West Bengal, India; ${ }^{2}$ Department of Agricultural Engineering, Visva \\ Bharati, Sriniketan - 731 236, West Bengal, India
}

\begin{abstract}
The present study was conducted to see the effect of pomegranate peel powder (PPP) on chicken meatballs from spent layers at three different levels (i.e., 1, 1.5 and $2 \%$ based on w/w). The effects of this powder on physico-chemical characteristics, texture profiles, microbial counts and sensory attributes were evaluated. Results showed that the addition of PPP significantly $(\mathbf{p}<0.05)$ improved the cooking yield, total ash and crude fibre of meat products. The treated products had significantly $(\mathbf{p}<\mathbf{0 . 0 5})$ lower values of peroxide and thiobarbituric acid (TBA) value and higher value of 1, 1-diphenyl2 picrylhydrazyl (DPPH) radical scavenging activity. The treated products had better sensory and textural properties than control. Shelf life is also enhanced in treated products during products stored at refrigerated temperature of $4 \pm 1{ }^{\circ} \mathrm{C}$ for a period of 15 days. The results demonstrated that PPP can be used in meat industry and other muscle food industries to increase the product stability and storability without affecting its quality and acceptability as well as to fulfill the consumer expectations for making the products healthy by reducing fat content.
\end{abstract}

Key words: Chicken meatballs, Pomegranate peel powder, Spent layers

\section{Highlights}

- PPP has high phenolic compounds and antioxidants properties.

- PPP significantly reduced the peroxide value and lipid oxidation of meat products.

- PPP could be used as natural additive to enhance the shelf life of meat products.

- PPP could be used in the formation of healthy, stable and wholesome meat products.

\section{INTRODUCTION}

Pomegranate peel powder is considered to provide a novel source of natural antioxidants agents, dietary fibre and overall nutritional properties due to its higher phenolic compounds and antioxidant properties (Quideau et al., 2011; Smaoui et al., 2019; Gullón et al., 2020) which provide numerous health benefits such as their ability to decrease blood cholesterol level, improve insulin response, minimise postprandial blood glucose, insulin, and triglyceride concentrations, reduce hyperlipidemia and hypertension, contribute to gastrointestinal health and prevent of certain cancers such as colon cancer (Ranjitha et al.,
2018). It also acts as antimicrobial agents due to possess of gallic acid, ellagic acid and punicalagin, along with their free radical scavenging properties (Das et al., 2021). It exhibits antibacterial activities against intestinal flora, especially enteric pathogens such as Escherichia coli, Salmonella spp., Shigella spp., and Vibrio cholera (Negi et al., 2003; Gullon et al., 2016; Kaur et al., 2018; Karthikeyan and Vidya, 2019; Singh et al., 2019).

Meat has a high biological value and is a good source of proteins and is an ideal source of soluble minerals, vitamins, essential fats, amino acids and many other nutrients having a 
specific function to the body (Biesalski, 2005; Gálvez et al., 2019; Das et al., 2020). Due to its rich nutritional profile, meat and meat products are highly susceptible for microbial deterioration (Lorenzo et al., 2014; Cunha et al., 2018; Lorenzo et al., 2018; Domínguez et al., 2019). Simultaneously, meat also contains metal catalysts, haem pigment, oxidizing agents, and unsaturated fatty acids which are responsible for protein and fat oxidation especially when exposed to extreme environmental conditions such as high temperature, air, and light (El-Hadary and Taha, 2020). Therefore, the meat products become rancid and several sensory attributes of the products, such as changes of colour, flavour and structural changes of products, have been deteriorated during storage period, and consequently shorten the shelf life of the products (Hygreeva and Pandey, 2016; Pateiro et al., 2018; Das et al., 2019; de Carvalho et al., 2019; Domínguez et al., 2019; Madane et al., 2019; Banerjee et al., 2020).

Meatballs are emulsion type products and are used at fast food outlets. Due to its short shelf life, as various deteriorative changes occurred during storage period, an experiment was conducted to see the effect of pomegranate peel powder on chicken meatballs from spent layers at refrigerated temperature $\left(4 \pm 1^{\circ} \mathrm{C}\right)$ on various qualities attributes such as physicochemical characteristics, antioxidant properties, antimicrobial properties, sensory properties and shelf life of the products.

\section{MATERIALS AND METHODS}

Raw materials: Spent layer birds were procured from State Poultry Farm, Tollygunge, Kolkata. Spent layers birds were subjected to ante-mortem inspection and maintained for 6 hours by giving water only. The age of all birds was above 80 weeks. After observing 6 hours in ante-mortem inspection, spent layers birds were found free from any abnormalities. Slaughter and dressing was done in the Poultry Processing unit of the Department of Livestock Products Technology, West Bengal University of Animal and Fishery Sciences, Kolkata as per the standard procedure mentioned by Sahoo and Panda (1983) with little bit modification.

Outer covers of pomegranate fruit were removed and placed into sun dried. After completely drying, it ran into the grinder. This powder was then sieved through a fine mesh in order to obtain a powder with an average particle size of $<1.0 \mathrm{~mm}$ (Costa et al., 2009).

Condiment mixture was prepared by blending peeled and sliced onion, garlic and ginger in the ratio of $3: 1: 1$, respectively, in a fine paste. For spice mixtures, aniseed (saunf), black pepper (kali mirch), red chilli (lal-mirch), caraway (shahi-jeera) seed, cinnamon (dalchini), cardamom (elaichi), clove (laung), coriander (dhaniya), cumin (jeera) seed, turmeric (haldi), nutmeg (jaiphal), mace (javitri), dried ginger (saunth) were taken appropriately and then those spices are powdered separately and mixed thoroughly.

Meatball emulsions: The meat was weighed and cut into small chunks and placed in the meat mincer. Meat was minced by using a $10 \mathrm{~mm}$ plate followed by a $5 \mathrm{~mm}$ diameter plate subsequently. Meatballs emulsions were prepared by adding lean meat $(70 \%)$, rice bran oil $(7.0 \%)$, ice flakes $(8.7 \%)$, salt (1.6\%), refined wheat flour $(5 \%)$, dry spice mix $(1.80 \%)$, condiment mixture (4\%), egg albumin $(1.285 \%)$, sugar $(0.3 \%)$, tripolyphosphate $(0.3 \%)$, and sodium nitrite $(0.015 \%)$.

Meatballs preparation: Meatball emulsion was divided equally into 4 parts. One is for control and three were divided for treatments. Treatments were treated with pomegranate peel powder at three different levels viz $1.0 \%, 1.5 \%$ and $2.0 \%$, respectively, on w/w basis. Now, uniformed meatballs (diameter $2 \mathrm{~cm}$ ) were prepared from each portion (total 4 portions) mechanically. The individual part of meatballs (total 4 parts) was placed in metal containers and steam cooked at $121^{\circ} \mathrm{C}$ temperature for 20 minutes under a pressure of $6.8 \mathrm{~kg}$ (Kumar et al., 2013). After that, cooked meatballs were cooled at room temperature. One portion from each part was taken for analysis on 0 day and the rest of the portions were kept under refrigerated condition $\left(4 \pm 1^{\circ} \mathrm{C}\right)$ for further analysis.

Parameters tested: Physico-chemical parameters such as $\mathrm{pH}$, cooking yield percentage, water hold 
ing capacity, proximate analysis and texture profile analysis were determined and methodologies were followed as per procedure set up by Troutt et al. (1992), Murphy et al. (1975), Dzudie et al. (2004), AOAC (2001), Bourne (1978), respectively.

Different oxidation and antioxidant properties such as peroxide value, DPPH scavenging activity assay and TBA value were determined and the methodologies were followed as per procedure described by Koniecko (1979), Kato et al. (1988) and Tarladgis et al. (1960), respectively.

Microbiological parameters which are generally responsible for deterioration of the meat products were also tested. Total plate count, yeast and mould count, Staphylococcus aureus, lactic acid bacteria, Escherichia coli, total Coliform count and Salmonella sp. were determined and the procedure was followed as mentioned by APHA (2001) and the same procedure was followed for shelf life studies in which products were kept under refrigerated conditions at $4 \pm 1^{\circ} \mathrm{C}$ for 15 days.

Ten trained sensory panelists were performed for sensory analysis as it was described by Wichchukit and O'Mahony (2015). Sensory tests were conducted on 0 day, 3rd day, 5th day, 7 th day and 15 th day.

Statistical analysis: All data were analyzed in IBM $®$ SPSS $®$ software using a general linear model. Univariate data were analyzed by the statistical method of ANOVA according to Tukey's HSD (Honest Significant Difference) test (Tukey, 1949). All the results were presented in term of mean and standard error (SE). A probability value of $(\mathrm{p}<0.05)$ was noted as significant and probability value of $(\mathrm{p}<0.01)$ was noted as highly significant.

\section{RESULTS}

Physico-chemical properties: Table 1 shows the cooking yield percentage and Fig. 1 shows the $\mathrm{pH}$ and water holding capacity indicating the effect of pomegranate peel powder for both control and meatballs treated with different percentages of pomegranate peel powder (PPP). The mean value showed gradual increase in the

Table. 1. Effect of cooking yield of cooked spent layers chicken meatballs from different treatment groups

\begin{tabular}{ll}
\hline Treatment & Cooking yield $(\%)$ \\
\hline Control & $82.45 \pm 0.09^{\mathrm{a}}$ \\
PPP $1 \%$ & $84.35 \pm 0.09^{\mathrm{b}}$ \\
PPP $1.5 \%$ & $86.10 \pm 0.12 \mathrm{c}$ \\
PPP 2\% & $87.35 \pm 0.09^{\mathrm{d}}$ \\
\hline
\end{tabular}

$\mathrm{N}=4$, Data (Mean \pm standard error) with different small letter superscripts in the same column differ significantly $(\mathrm{p}<0.05)$
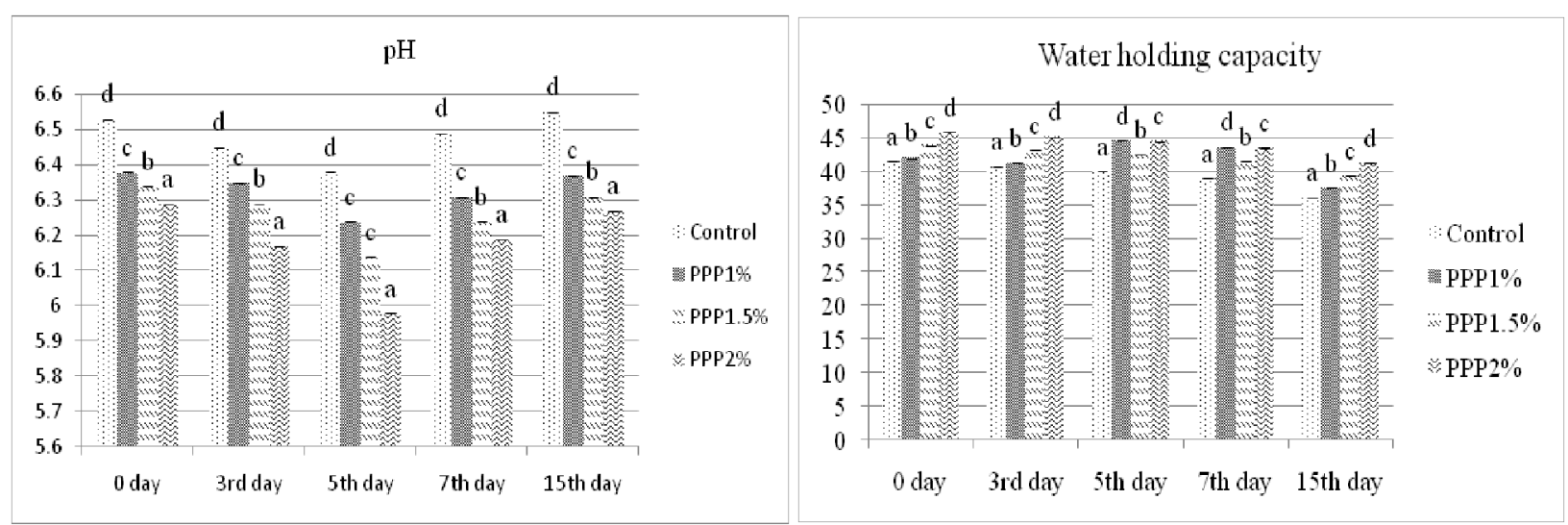

[Values of means \pm standard error (SE) of quadruplets independent experiments. Different small letters indicate signiûcant differences $(\mathrm{p}<0.05)$ within the samples in the same day]

Fig. 1. Effect of PPP on pH and water holding capacity of spent layer chicken meatballs 

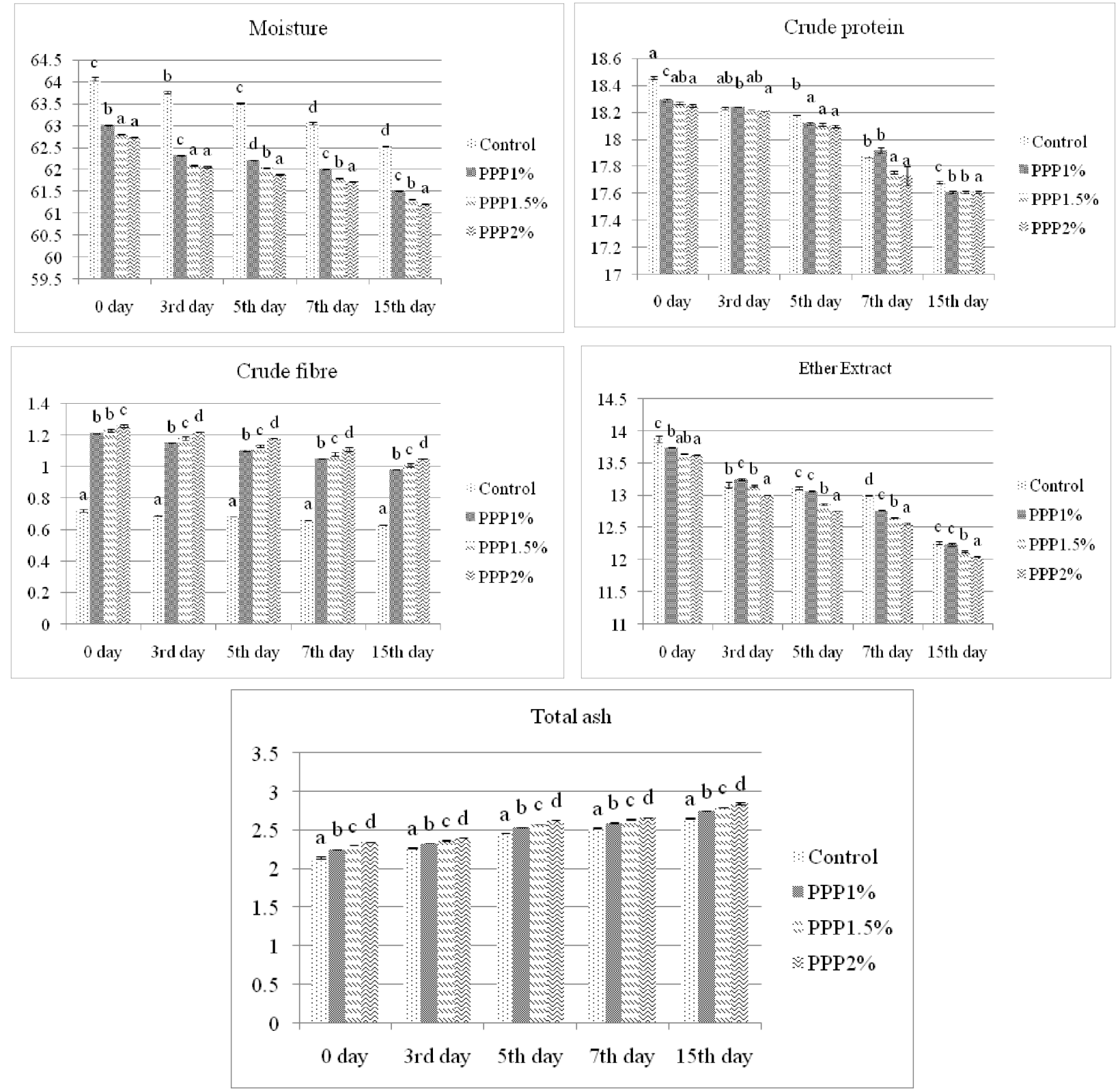

[Values of means \pm standard error (SE) of quadruplets independent experiments. Different small letters indicate signiûcant differences $(\mathrm{p}<0.05)$ within the samples in the same day]

Fig. 2. Effect of PPP on proximate analysis of spent layer chicken meatballs

cooking yield when increasing the PPP\% in the meatballs. $\mathrm{pH}$ of the treated products decreases with the increase of $\mathrm{PPP} \%$, whereas, water holding capacity increased significantly $(\mathrm{p}<0.05)$ with the increase of $\mathrm{PPP} \%$.

Proximate analysis: Proximate analysis shows the significant effect of PPP on spent layers cooked meatballs (Fig. 2). The amount of crude fibre, total ash increased significantly $(\mathrm{p}<0.05)$ due to increase of PPP\%. On the other hand moisture percentage, crude protein, crude fat were decreased significantly $(\mathrm{p}<0.05)$ with the increase of $\mathrm{PPP} \%$.

Oxidation and anti-oxidative properties: Fig. 3 shows the oxidation and anti-oxidative properties of PPP. Peroxide and TBA value 

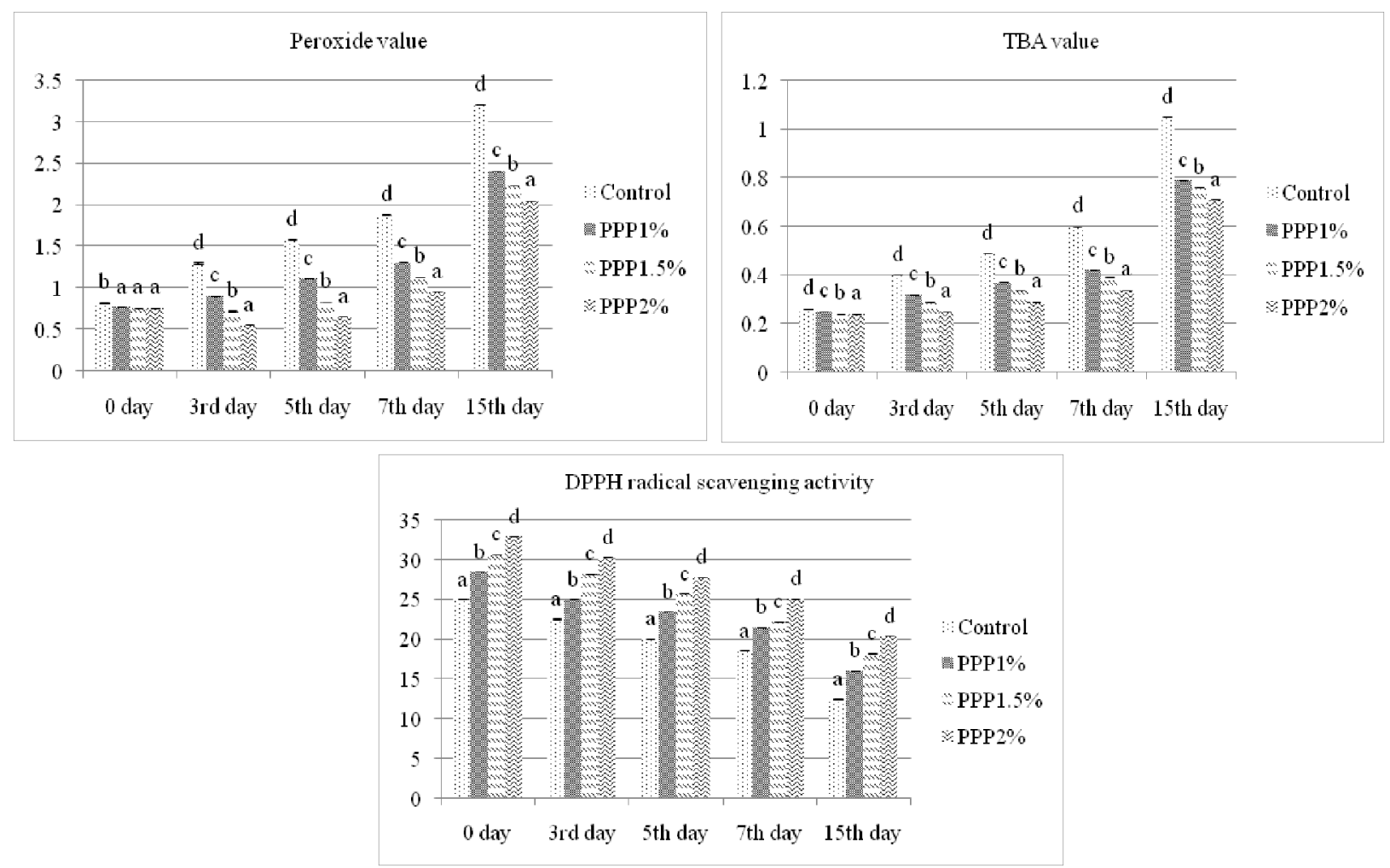

[Values of means \pm standard error (SE) of quadruplets independent experiments. Different small letters indicate signiûcant differences $(\mathrm{p}<0.05)$ within the samples in the same day]

Fig. 3. Effect of PPP on oxidation and antioxidative properties of spent layer chicken meatballs
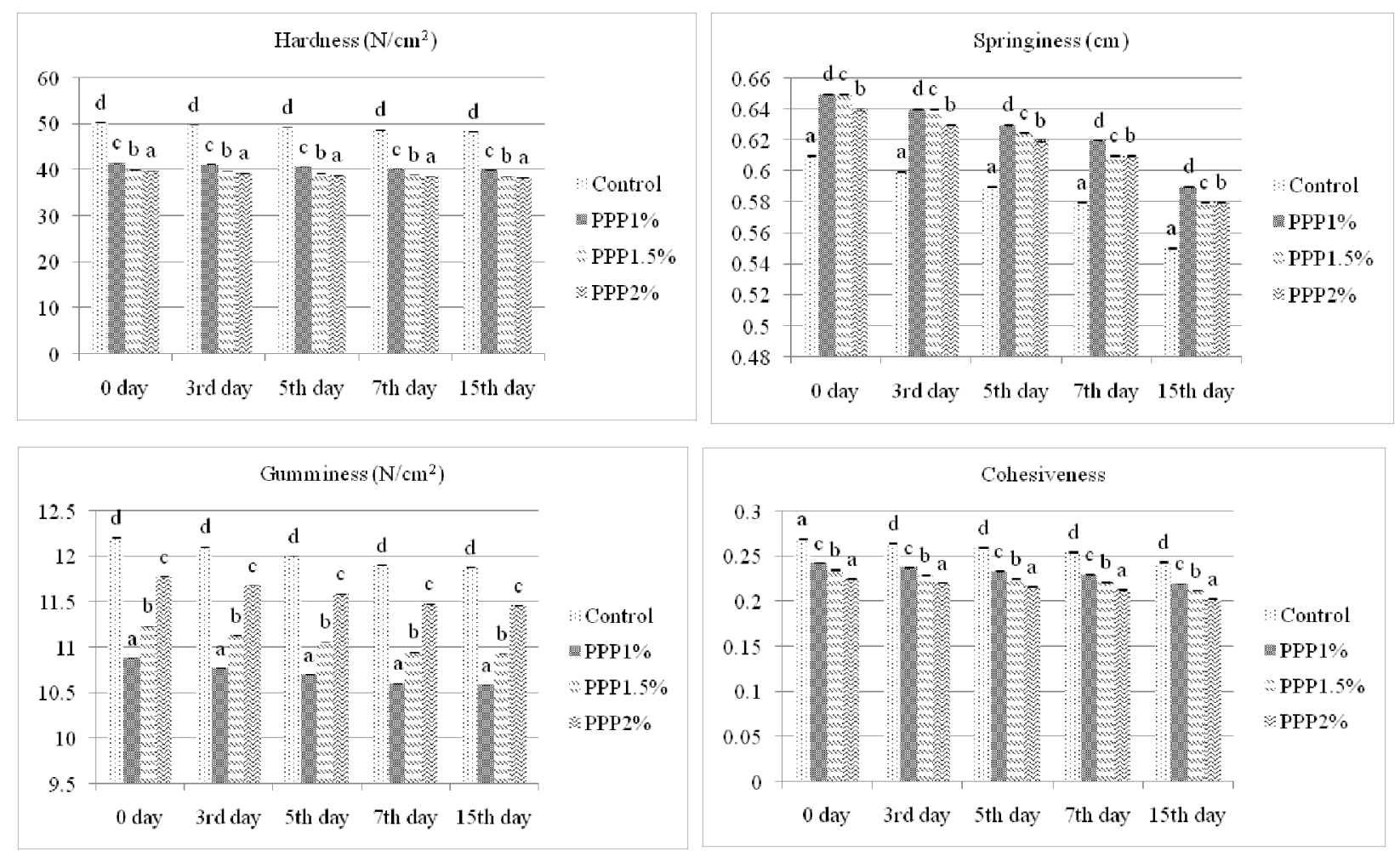




[Values of means \pm standard error (SE) of quadruplets independent experiments. Different small letters indicate signiûcant differences $(\mathrm{p}<0.05)$ within the samples in the same day]

Fig. 4. Effect of PPP on textural attributes of spent layer chicken meatballs
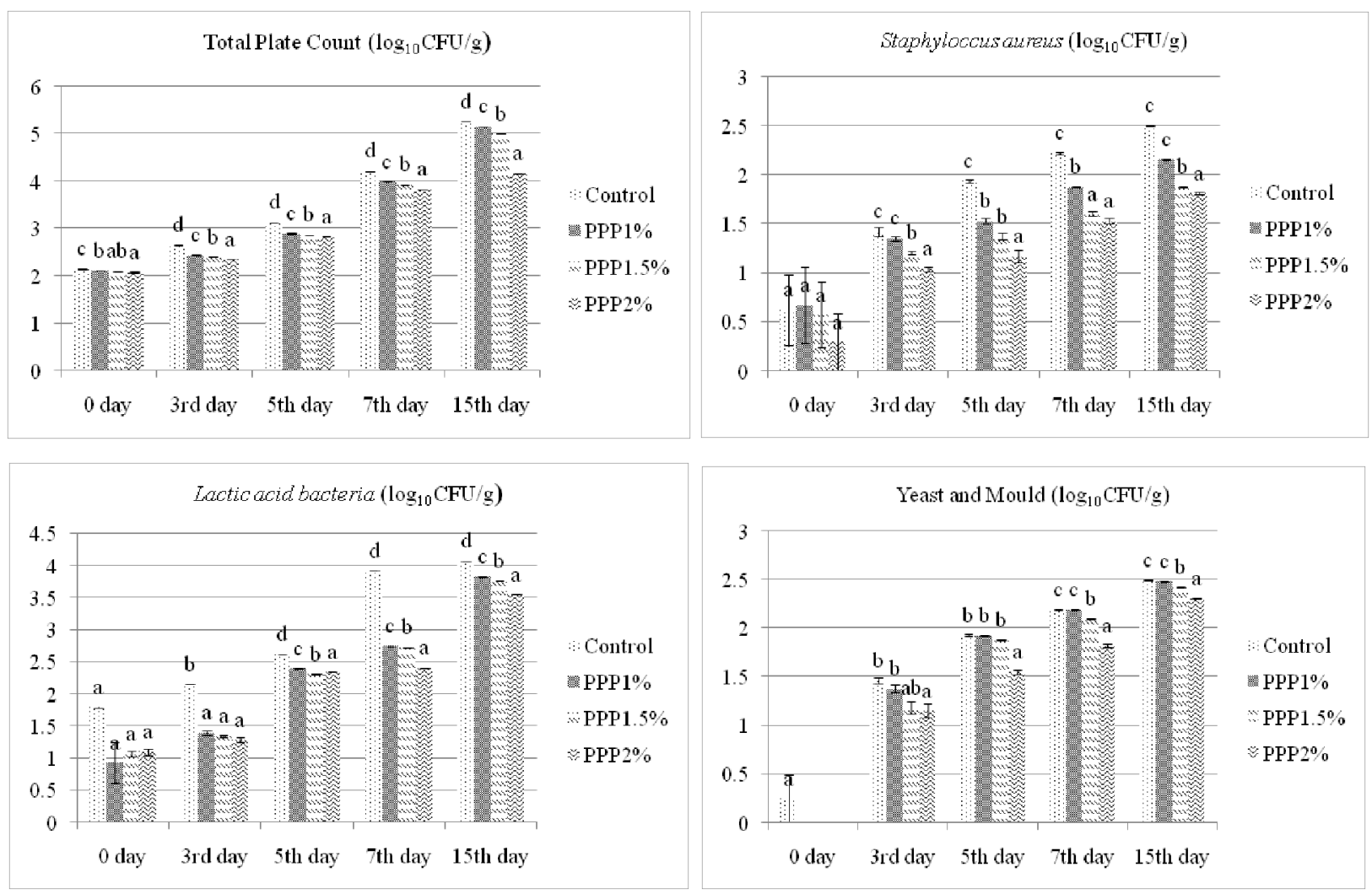

[Values of means \pm standard error (SE) of quadruplets independent experiments. Different small letters indicate signiûcant differences $(\mathrm{p}<0.05)$ within the samples in the same day]

Fig. 5. Effect of PPP on microbial quality of spent layer chicken meatballs

reduced significantly $(\mathrm{p}<0.05)$ with the increase of fruit by products in the meatballs. DPPH radical scavenging activity increased significantly $(\mathrm{p}<0.05)$ with the increase of PPP $\%$ in the meatballs.
Texture profile analysis: The control samples had the higher hardiness, cohesiveness, gumminess and chewiness values, whereas for springiness, the samples treated with $1 \%$ PPP showed the highest. With an increase of the 

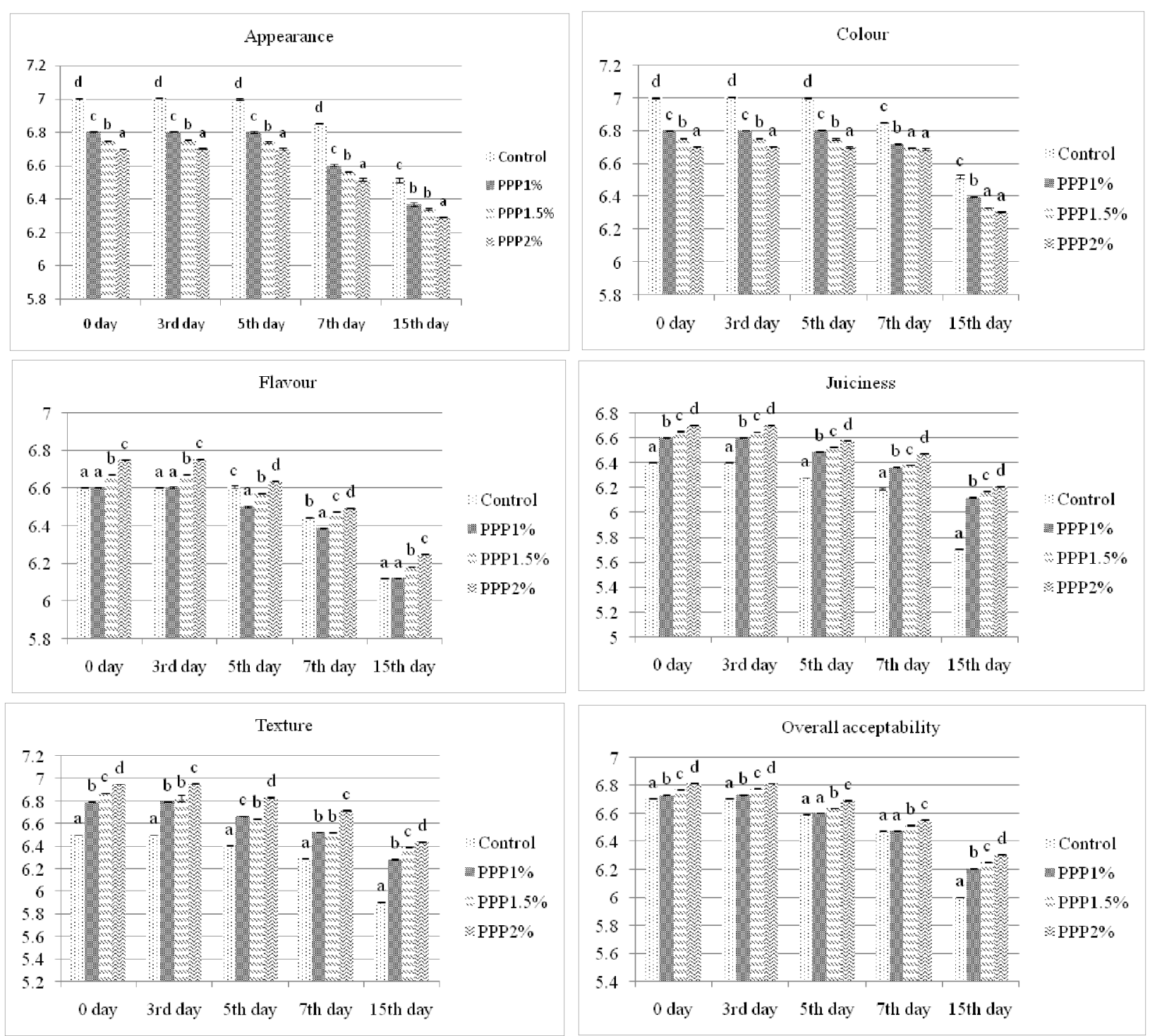

[Values of means \pm standard error (SE) of quadruplets independent experiments. Different small letters indicate signiûcant diûerences $(\mathrm{p}<0.05)$ within the samples in the same day]

\section{Fig. 6. Effect of PPP on sensory attributes of spent layer chicken meatballs}

storage period, there was a gradual decrease in hardiness, springiness, cohesiveness, gumminess and chewiness. All values were statistically significant $(\mathrm{p}<0.05)$.

Microbiological analysis: Evaluation of TPC, yeast and mould Count, Staphylococcus aureus and Lactic acid bacteria showed that incorporation of PPP on chicken meatballs from spent layers was very much effective $(\mathrm{P}<0.05)$ in controlling the microbial counts throughout the 15 days of storage period kept at refrigerator temperature of $4 \pm 1^{\circ} \mathrm{C}$. Microbial counts in meat products decreased in a manner proportional to the levels of PPP. However, detection of Salmonella spp., Escherichia coli and total Coliform count were also performed, but those microbes were not detected throughout the storage period of 15 days.

Sensory analysis: Data of organoleptic attributes of the spent layers chicken meatballs 
showed that the addition of PPP made significant $(\mathrm{P}<0.05)$ effects on various attributes. Appearance and colour decreased with the increase of PPP $\%$. On the other hand, juiciness, flavour, texture and overall acceptability increased with the increase of PPP $\%$.

\section{DISCUSSION}

Physico-chemical properties: Cooking yield is generally performed to see the influence of nonmeat ingredients, such as macromolecular hydrocolloids, starches and fibre which are known to have water binding capacity, on the treated products. The mean value showed gradual increase in the cooking yield when increasing the PPP \% in the meatballs. A particular trend of increase in cooking yield with increase of fruit by products powder concentration was observed for treated meatballs. The reason behind such findings may be due to the presence of fibre which could have retained moisture in the final product and thus increase its cooking yield. The observation of this study was synchronized with the observation made by Huda et al. (2014), Banerjee et al. (2015), Ho and Dahri (2016), Das et al. (2008) and Morsy et al. (2018).

$\mathrm{pH}$ measurement is required to see the freshness of products which in turn determines the quality and shelf life of meat products (Das et al., 2021). Incorporation of PPP decreased the $\mathrm{pH}$ of the cooked meatballs. Similar findings were reported by Naveena et al. (2008), Habib et al. (2018), Firuzi et al. (2019) and Mehdizadeh et al. (2020). Whereas, Sharma and Yadav (2020) found non-significantly lower $\mathrm{pH}$ in cooked chicken patties prepared from pomegranate by-products and extracts. Increase of water holding capacity was observed with the increase of PPP \% in the meatballs. This might be due to the fact that higher levels of PPP \% retain more water and thereby increase the water holding capacity. The results obtained in this study were in commensurate with the studies conducted by Akhtar et al. (2015) in raw beef sausage incorporated with $3 \%$ pomegranate rind powder, Morsy et al. (2018) in beef meatballs using lyophilized pomegranate peel nanoparticles, Serdaroglu et al. (2005) in frozen low fat beef meatballs containing legume flours and Das et al. (2008) in frozen goat meat nuggets using textured soy granules and full fat soy paste.

Proximate analysis: Moisture and fat percentage decreased gradually with the increased concentration of PPP. Similar findings were also observed by Lubis et al. (2020) and Mohammad et al. (2021). Reduction of crude protein percentage was observed with the increase of PPP in the meatballs. According to Ranjitha et al. (2018), pomegranate peel powder contains $3.74 \%$ protein. This factor aids to the protein content of the spent layer chicken meatballs. Although meat does not contain any fibre, a small amount of crude fibre content was found in control treatments. This may be due to the presence of crude fibre contributed by spices and condiments present in control treatments. Therefore, an increase of crude fibre percentage was observed with the increase of PPP in the meatballs. Increase of total ash percentage was observed with the increase of PPP in the meatballs. This finding are conforming with the findings made by Al-Sayed and Abdelrahman (2013), Verma et al. (2013), Das et al. (2014), Banerjee et al. (2015), Ho and Dahri (2016), Naknaen et al. (2016), Thomas et al. (2016) and Vivar-Vera et al. (2018). But, this observation is not conforming to the observations made by Bhat et al. (2015) who added aloe vera gel in chicken nuggets and Huda et al. (2014) who incorporated apple pomace in mutton nuggets. The results showed the opposite because they added gel and paste form, respectively, which added moisture in the final products and thus reduced the total ash content in the finished products.

Oxidation and anti-oxidative properties: Reduction of peroxide value and TBA value were observed with the increase of PPP in the meatballs. Whereas, an increased of DPPH radical scavenging activity was observed with 
the increase of PPP in the meatballs. This result indicates that PPP is having a noticeable effect on scavenging free radicals. Pomegranate peel powders are high in antioxidant activity due to presence of high content of phenolic acids and flavonoids (Derakhshan et al., 2018; Ranjitha et al., 2018; de Oliveira et al., 2020). So, this may be the reason for the decrease in oxidation in treated meat.

Texture profile analysis: Reduction of hardness, springiness, and cohesiveness were observed with the increase of PPP in the meatballs. Hardness depends on the moisture percentage of meatballs. Springiness is the ability of the product to regain its shape after deformation during the compression cycle. Springiness values were associated with the elastic properties of meatballs. So, reduction of springiness indicates that the elasticity of meatballs is decreased with the increase in the level of incorporation of phytomaterials (Rindhe et al., 2018). Increases of gumminess and chewiness were observed with the increase of PPP in the meatballs. Gumminess and chewiness values are directed by hardness, cohesiveness and springiness values of the product. Incorporation of PPP in the meatballs leads to increase in chewiness significantly $(\mathrm{P}<0.05)$. These findings are consistent with the results reported by Rindhe et al. (2018) and Das et al. (2020).

Microbiological analysis: A trend has been found that decrease of total plate count, yeast and mould, Staphylococcus aureus, Lactic acid bacteria were observed with the increase of PPP in the meatballs. This may be due to PPP having antimicrobial properties due to contain of total flavonoids and tannins content. Similar findings were reported by Hayrapetyan et al. (2012), Tayel et al. (2012), Casquete et al. (2015), Ismail et al. (2016), Martínez et al. (2019), Shahamirian et al. (2019) and Chen et al. (2020).

Sensory analysis: Appearance and colour were significantly $(\mathrm{P}<0.05)$ lower than control which is opposite to Kumar et al. (2021) who reported that the effect of goat meatballs were improved with PP. Increase of flavour was observed with the increase of PPP in the meatballs. This could be due to the reason that PPP might have acted as stabilizing agent for retaining the fiavour by inhibiting the lipid oxidation. Meatballs containing PPP were found to be more juice than the control, which could be attributed to the increased moisture retention of the product during cooking. Similar findings were reported by Kumar et al. (2021). Overall acceptability scores in treated products remained stable and were acceptable even on the $15^{\text {th }}$ day of storage.

The present study showed that the PPP can be used in the formation of healthy, stable and wholesome meat products for having properties of antioxidant, antimicrobial and bioactive components. Incorporation of PPP in the meat products has higher cooking yield, crude fibre and lesser in fat content along with great positive effects on texture profiles, organoleptic attributes and microbiological parameters. Hence, PPP could be used in meat industry and other muscle food industries to make the value added products by increasing the product stability and storability without affecting its quality and acceptability as well as by fulfilling the consumer expectations for making the products healthy by reducing fat content and increasing crude fibre content.

Conflict of interest: Authors have no conflict of interest in this study.

Author's contribution: DD: Performed this research work and made a preliminary draft of the manuscript; SB: Made conceptualization of this research work and critically redrafted; $O B$, GP and PK: Helped in performing the different methods and analysis the data.

\section{ACKNOWLEDGEMENT}

The authors express their sincere gratitude to Department of Livestock Products Technology, F/O Veterinary and Animal Sciences, West Bengal University of Animal and Fishery Sciences, Kolkata for all the support provided. 


\section{REFERENCE}

Akhtar S, Ismail T, Fraternale D and Sestili P, 2015. Pomegranate peel and peel extracts: chemistry and food features. Food Chem, 174: 417-25, doi: 10.1016/j.foodchem.2014.11.035

Al-sayed HMA and Abdelrahman RA, 2013. Utilization of watermelon rinds and sharlyn melon peels as a natural source of dietary fiber and antioxidants in cake. Ann Agric Sci, 58(1): 83-95, doi: 10.1016/j.aoas.2013.01.012

AOAC, 2001. Association of Official Analytical Chemists International. Official Methods of Analysis. $17^{\text {th }}$ edn., AOAC Inc., Arlington, USA

APHA, 2001. American Public Health Association. Frances PD, and Keith I (Eds). Compendium of Methods for the Microbiological Examination of Foods. Washington, DC

Banerjee DK, Das AK, Banerjee R, Pateiro M, Nanda PK et al., 2020. Application of enoki mushroom (Flammulina velutipes) stem wastes as functional ingredients in processed meat. Foods, 9: 432, doi: $10.3390 /$ foods 9040432

Banerjee R, Verma AK and Narkhede HP, 2015. Cauliflower powder in pork meatballs: effects on quality characteristics and oxidative stability. Fleischwirtschaft Int, 1: 97-102

Bhat ZF, Kumar S and Kumar P, 2015. Effect of Aloe vera on the lipid stability and storage quality of chicken nuggets. Nutr Food Sci, 45: 54-67, doi: 10.1108/NFS-04-2014-0034

Biesalski HK, 2005. Meat as a component of a healthy diet-are there any risks or benefits if meat is avoided in the diet? Meat Sci, 70: 509-524, doi: 10.1016/j.meatsci.2004.07.017

Bourne MC, 1978. Texture profile analysis. Food Technol, 32(7): 62-66

Casquete R, Castro SM, Martín A, Ruiz-Moyano S, Saraiva JA et al., 2015. Evaluation of the effect of high pressure on total phenolic content, antioxidant and antimicrobial activity of citrus peels. Innov Food Sci Emerg Technol, 31: 37-44, doi: 10.1016/j.ifset.2015.07.005

Chen J, Liao C, Ouyang X, Kahramanoðlu I, Gan Y et al., 2020. Antimicrobial activity of pomegranate peel and its applications on food preservation. J Food Qual, doi: 10.1155/2020/8850339

Costa J, Felipe É, Maia G, Hernandez F and Brasil I, 2009. Production and characterization of the cashew apple (Anacardium occidentale L.) and guava (Psidium guajava L.) fruit powders. J Food Process Preserv, 33: 299-312, doi: 10.1111/j.17454549.2008.00342.x
Cunha LCM, Monteiro MLG, Lorenzo JM, Munekata PES, Muchenje V et al., 2018. Natural antioxidants in processing and storage stability of sheep and goat meat products. Food Res Int, 111: 379-390, doi: 10.1016/j.foodres.2018.05.041

Das AK, Rajkumar V and Verma AK, 2014. Bael pulp residue as a new source of antioxidant dietary fiber in goat meat nuggets. J Food Process Preserv, 39(6): 1-10, doi: 10.1111/jfpp.12392

Das AK, Anjaneyulu ASR, Gadekar YP, Singh RP and Pragati H, 2008. Effects of full fat soy paste and textured soy granules on quality and shelf-life of goat meat nuggets in frozen storage. Meat Sci, 80: 607-614, doi: 10.1016/j.meatsci.2008.02.011

Das AK, Das A, Nanda PK, Madane P, Biswas S et al., 2020. A comprehensive review on antioxidant dietary fibre enriched meat-based functional foods. Trends Food Sci Technol, 99: 323-336, doi: 10.1016/j.tifs.2020.03.010

Das AK, Nanda PK, Chowdhury NR, Dandapat P, Gagaoua M et al., 2021. Application of pomegranate by-products in muscle foods: oxidative indices, colour stability, shelf life and health benefits. Molecules, 26(2): 467, doi: 10.3390/molecules26020467

Das AK, Nanda PK, Das A and Biswas S, 2019. Hazards and safety issues of meat and meat products. In: Food Safety Human Health, pp 145-168, doi: 10.1016/B978-0-12-816333-7.00006-0

de Carvalho FAL, Lorenzo JM, Pateiro M, Bermúdez R, Purriños L et al., 2019. Effect of guarana (Paullinia cupana) seed and pitanga (Eugenia uniflora L.) leaf extracts on lamb burgers with fat replacement by chia oil emulsion during shelf life storage at $2^{\circ} \mathrm{C}$. Food Res Int, 125: 108554 , doi: 10.1016/j.foodres.2019.108554

de Oliveira FL, Arruda TY, da Silva Lima R, Casarotti $\mathrm{SN}$ and Morzelle MC, 2020. Pomegranate as a natural source of phenolic antioxidants: A review. J Food Bioact, 9, doi: 10.31665/JFB.2020.9214

Derakhshan Z, Ferrante M, Tadi M, Ansari F, Heydari A et al., 2018. Antioxidant activity and total phenolic content of ethanolic extract of pomegranate peels, juice and seeds. Food Chemical Toxicol, 114: 108-111, doi: 10.1016/ j.fct.2018.02.023

Domínguez R, Pateiro M, Gagaoua M, Barba FJ, Zhang $\mathrm{W}$ et al., 2019. A comprehensive review on lipid oxidation in meat and meat products. Antioxidants, 8(10): 429, doi: 10.3390/ antiox 8100429

Dzudie T, Kouebou CP, Essia-Ngang JJ and Mbofung 
CMF, 2004. Lipid sources and essential oils effects on quality and stability of beef patties. $\mathbf{J}$ Food Eng, 65: 67-72, doi: 10.1016/j.jfoodeng. 2003.12.004

El-Hadary AE and Taha M, 2020. Pomegranate peel methanolic-extract improves the shelf-life of edible-oils under accelerated oxidation conditions. Food Sci Nutr, 8: 1798-1811, doi: 10.1002/fsn3.1391

Firuzi MR, Niakousari M, Eskandari MH, Keramat M, Gahruie HH et al., 2019. Incorporation of pomegranate juice concentrate and pomegranate rind powder extract to improve the oxidative stability of frankfurter during refrigerated storage. LWT, 102: 237-245, doi: 10.1016/ j.lwt.2018.12.048

Gálvez F, Maggiolino A, Domínguez R, Pateiro M, Gil $\mathrm{S}$ et al., 2019. Nutritional and meat quality characteristics of seven primal cuts from 9-monthold female veal calves: A preliminary study. J Sci Food Agr, 99(6): 2947-2956, doi: 10.1002/ jsfa.9508

Gullon B, Pintado ME, Pérez-Álvarez JA and ViudaMartos M, 2016. Assessment of polyphenolic profile and antibacterial activity of pomegranate peel (Punica granatum) flour obtained from coproduct of juice extraction. Food Control, 59: 9498, doi: 10.1016/j.foodcont.2015.05.025

Gullón P, Astray G, Gullón B, Tomasevic I and Lorenzo JM, 2020. Pomegranate peel as suitable source of high-added value bioactives: tailored functionalized meat products. Molecules, 25(12): 2859, doi: 10.3390/molecules25122859

Habib H, Siddiqi RA, Dar AH, Dar MA, Gul K et al., 2018. Quality characteristics of carabeef nuggets as affected by pomegranate rind powder. J Food Meas Charact, 12(3): 2164-2173, doi: 10.1007/ s11694-018-9832-2

Hayrapetyan H, Hazeleger WC and Beumer RR, 2012. Inhibition of Listeria monocytogenes by pomegranate (Punica granatum) peel extract in meat pate at different temperatures. Food Control, 23: 6672, doi: 10.1016/j.foodcont. 2011.06.012

Ho LH and Dahri NC, 2016. Effect of watermelon rind powder on physico- chemical, textural and sensory properties of wet yellow noodles. Cyta J Food, 14: 465-472,

Huda AB, Parveen S, Rather SA, Akhter R and Hassan M, 2014. Effect of incorporation of apple pomace on the physico-chemical, sensory and textural properties of mutton nuggets. Int J Adv Res, 2(4): 974-983
Hygreeva D and Pandey MC, 2016. Novel approaches in improving the quality and safety aspects of processed meat products through high pressure processing technology - A review. Trends Food Sci Technol, 54: 175-185, doi: 10.1016/ j.tifs.2016.06.002

Ismail T, Akhtar S, Sestili P, Riaz M, Ismail A et al., 2016. Antioxidant, antimicrobial and urease inhibitory activities of phenolics-rich pomegranate peel hydro-alcoholic extracts. J Food Biochem, 40(4): 550-558, doi: 10.1111/ jfbc. 12250

Karthikeyan G and Vidya AK, 2019. Phytochemical analysis, antioxidant and antibacterial activity of pomegranate peel. Res J Life Sci Bioinfo Pharmaceut Chem Sci, 5(1): 218-231, doi: 10.26479/2019.0501.22

Kato K, Terao S, Shimamoto N and Hirata M, 1988. Studies on scavengers of active oxygen species. 1. Synthesis and biological activity of 2-Oalkylascorbic acids. J Med Chem, 31(4): 793-798, doi: 10.1021/jm00399a019

Kaur R, Kaushal S and Sharma P, 2018. Antimicrobial and antioxidant potential of pomegranate (Punica granatum L.) peel. Int J Chem Stud, 6: 3441-3449

Koniecko EK, 1979. In: Handbook for Meat Chemists. Chapter 6, Avery Publishing Group Inc., Wayne, New Jersey, USA, pp 68-69

Kumar A, Kumar A, Chavhan DM, Jat RC and Sharma A, 2021. Effect of incorporation of pomegranate peel powder and essential oils on proximate composition and sensory qualities of goat meat balls. J Entomol Zool Stud, 9(2): 332-335

Kumar V, Biswas AK, Sahoo J, Chatli MK and Sivakumar S, 2013. Quality and storability of chicken nuggets formulated with green banana and soybean hull flours. J Food Sci Technol, 50: 10581068, doi: 10.1007/s13197-011-0442-9

Lorenzo JM, Batlle R and Gómez M, 2014. Extension of the shelf-life of foal meat with two antioxidant active packaging systems. LWT Food Sci Technol, 59: 181-188, doi: 10.1016/ j.lwt.2014.04.061

Lorenzo JM, Munekata PES, Sant AS, Baptista R, Barba FJ et al., 2018. Main characteristics of peanut skin and its role for the preservation of meat products. Trends Food Sci Technol, 77: 1-10, doi: 10.1016/j.tifs.2018.04.007

Lubis N, Jefri Agustiono J, Ismail D and Pradana TG, 2020. Effect of red dragon fruit peels (Hylocereus polyrhizus) as a natural dye and preservatives on chicken nuggets. Int J Res Rev, 7(3): 168-174 
Madane P, Das AK, Pateiro M, Nanda PK, Bandyopadhyay S et al., 2019. Drumstick (Moringa oleifera) flower as an antioxidant dietary fibre in chicken meat nuggets. Foods, 8: 307, doi: 10.3390/foods 8080307

Martínez L, Castillo J, Ros G and Nieto G, 2019. Antioxidant and antimicrobial activity of rosemary, pomegranate and olive extracts in fish patties. Antioxidants (Basel), 8(4): 86, doi: 10.3390/antiox 8040086

Mehdizadeh T, Tajik H, Langroodi AM, Molaei R and Mahmoudian A, 2020. Chitosan-starch film containing pomegranate peel extract and thymus kotschyanus essential oil can prolong the shelf life of beef. Meat Sci, 163: 108073, doi: 10.1016/ j.meatsci.2020.108073

ohammad SM, Hisham AAB, Mustapa NA, Chan KW and Zawawi N, 2021. Proximate analysis, antioxidant activity, and antibacterial activity of fish sausages fortified with bee bread extract. J Food Qual: 6657553, doi: 10.1155/2021/ 6657553

Morsy MK, Mekawi E and Elsabagh R, 2018. Impact of pomegranate peel nanoparticles on quality attributes of meatballs during refrigerated storage. LWT, 89: 489-495, doi: 10.1016/ j.lwt.2017.11.022

Murphy EW, Criner PE and Grey BC, 1975. Comparison of methods for calculating retentions of nutrients in cooked foods. J Agr Food Chem, 23: 1153-1157, doi: 10.1021/jf60202a021

Naknaen P, Itthisoponkul T, Sondee A and Angsombat $\mathrm{N}, 2016$. Utilization of watermelon rind waste as a potential source of dietary fiber to improve health promoting properties and reduce glycemic index for cookie making. Food Sci Biotechnol, 25(2): 415-424, doi: 10.1007/s10068-016-0057-z

Naveena BM, Sen AR, Kingsly RP, Singh DB and Kondaiah N, 2008. Antioxidant activity of pomegranate rind powder extract in cooked chicken patties. Int J Food Sci Tech, 43: 18071812, doi: 10.1111/j.1365-2621.2007.01708.x

Negi PS, Jayaprakasha GK and Jena BS, 2003. Antioxidant and antimutagenic activities of pomegranate peel extracts. Food Chem, 80: 393397, doi: 10.1016/S0308-8146(02)00279-0

Pateiro M, Barba FJ, Domínguez R, Sant'Ana AS, Mousavi Khaneghah A et al., 2018. Essential oils as natural additives to prevent oxidation reactions in meat and meat products: A review. Food Res Int, 113: 156-166, doi: 10.1016/j.foodres.2018. 07.014
Quideau S, Deffieux D, Douat-Casassus C and Pouységu L, 2011. Plant polyphenols: chemical properties, biological activities, and synthesis. Angew Chem Int Ed, 50: 586-621, doi: 10.1002/anie. 201000044

Ranjitha J, Bhuvaneshwari G, Terdal D and Kavya K, 2018. Nutritional composition of fresh pomegranate peel powder. Int J Chem Stud, 6(4): 692-696

Rindhe SN, Chatli MK, Wagh RV, Kumar P, Malav OP et al., 2018. Development and quality of fiber enriched functional spent hen nuggets incorporated with hydrated wheat bran. Int J Curr Microbiol Appl Sci, 7(12): 3331-3345, doi: 10.20546/ijcmas.2018.712.384

Sahoo J and Panda PC, 1983. Effect of different scalding techniques on dressing yield of chicken and duck. Indian J Poult Sci, 18(2): 65-69

Serdaroglu M, Turp GY and Abrodimov K, 2005. Quality of low fat meat balls containing legume flours as extenders. Meat Sci, 70(1): 99-105, doi: 10.1016/j.meatsci.2004.12.015

Shahamirian M, Eskandari MH, Niakousari M, Esteghlal S, Gahruie HH et al., 2019. Incorporation of pomegranate rind powder extract and pomegranate juice into frozen burgers: oxidative stability, sensorial and microbiological characteristics. J Food Sci Technol, 56(3): 117483, doi: 10.1007/s13197-019-03580-5

Sharma P and Yadav S, 2020. Effect of incorporation of pomegranate peel and bagasse powder and their extracts on quality characteristics of chicken meat patties. Food Sci Anim Resour, 40: 388-400, doi: 10.5851/kosfa.2020.e19

Singh B, Singh JP, Kaur A and Singh N, 2019. Antimicrobial potential of pomegranate peel: A review. Int J Food Sci Tech, 54(4): 959-965, doi: 10.1111/ijfs. 13964

Smaoui S, Hlima HB, Mtibaa AC, Fourati M, Sellem I et al., 2019. Pomegranate peel as phenolic compounds source: advanced analytical strategies and practical use in meat products. Meat Sci, 158, doi: 10.1016/j.meatsci.2019.107914

Tarladgis BG, Watts BM and Yonathan M, 1960. A distillation method for the determination of malonaldehyde in rancid foods. J Am Oil Chem Soc, 37(1): 44-48, doi: 10.1007/BF02630824

Tayel AA, El-Tras WF, Moussa SH and El-Sabbagh SM, 2012. Surface decontamination and quality enhancement in meat steaks using plant extracts as natural biopreservatives. Foodborne Pathog Dis, 9: 755-761, doi: 10.1089/fpd.2012.1203 
Thomas R, Jebin N, Saha R and Sarma DK, 2016. Antioxidant and antimicrobial effects of kordoi (Averrhoa carambola) fruit juice and bamboo (Bambusa polymorpha) shoot extract in pork nuggets. Food Chem, 190: 41-49, doi: 10.1016/ j.foodchem.2015.05.070

Troutt ES, Hunt MC, Johnson DE, Claus JR, Kastner CL et al., 1992. Characteristics of low-fat ground beef containing texture-modifying ingredients. J Food Sci, 57: 19-24, doi: 10.1111/j.13652621.1992.tb05415.x

Tukey JW, 1949. Comparing individual means in the analysis of variance. Biometrics, 5(2): 99-114, doi: $10.2307 / 3001913$
Verma AK, Rajkumar V, Banerjee R, Biswas S and Das AK, 2013. Guava (Psidium guajava L.) powder as an antioxidant dietary fibre in sheep meat nuggets. Asian-Australas J Anim Sci, 26(6): 886-895, doi: 10.5713/ajas.2012.12671

Vivar-Vera MLA, Pérez-Silva A, Ruiz-López II, Hernández-Cázares AS, Solano-Barrera $\mathrm{S}$ et al., 2018. Chemical, physical and sensory properties of Vienna sausages formulated with a starfruit dietary fiber concentrate. J Food Sci Tech, 55(8): 3303-3313, doi: 10.1007/s13197-018-3265-0

Wichchukit S and O'Mahony M, 2015. The 9-point hedonic scale and hedonic ranking in food science: some reappraisals and alternatives. J Sci Food Agr, 95(11): 2167-2178, doi: 10.1002/jsfa.6993

Received - 26.09.2021, Accepted - 09.11.2021, Published-01.12.2021

Section Editor: Dr. A. K. Das, Member, Editorial Board 